\title{
Effect of Conservation Agriculture-based Technology on Yield and Economics of Paddy
}

\author{
Satyajeet $^{\text {1* }}$, S.P. Yadav ${ }^{2}$ and S.K. Dhanda ${ }^{3}$ \\ ${ }^{1}$ Krishi Vigyan Kendra, CCS HAU, Jhajjar, Haryana - 124103, India \\ ${ }^{2}$ CCS HAU, Regional Research Station, Bawal, India \\ ${ }^{3}$ Krishi Vigyan Kendra, Hisar, India \\ *Corresponding author
}

\section{A B S T R A C T}

\begin{tabular}{|l|}
\hline Ke y w o r d s \\
Conservation \\
technology, D.S.R., \\
paddy, Yield, \\
Economics and B:C \\
ratio
\end{tabular}

\section{Introduction}

Conservation agriculture, defined as a system encompassing minimal soil disturbance, permanent organic soil cover and crop rotation and/or associations (FAO, 2016), provides multiple benefits (Hobbs, 2007) including improved crop water relations, reduced soil erosion, reduced greenhouse gas emission and improved crop economic productivity. Further, the use of organic manure, compost and growing of green manure crops has also decreased considerably due to various reasons. Similarly water resources are under great

\begin{abstract}
Farmers' participatory front line demonstrations on method of sowing paddy with D.S.R. machine and traditional method of transplanting as local check were conducted at ten location during kharif (2014 and 2015) under CCS, HAU, Krishi Vigyan Kendra, Fatehabad, Haryana. The study reveals that on an average $52.07 \mathrm{q} / \mathrm{ha}$ yield of paddy (var. PUSA-1121) was recorded in demonstration plot as compare to $51.64 \mathrm{q} / \mathrm{ha}$ in local check which was 0.9 per cent higher over that of the local check. The data on economic parameters reveals that a net return of Rs. 55033 per ha was in demonstration compare to Rs.47123 per ha in local check. The benefit-cost (B:C) ratio was $1: 1.68$ and $1: 1.53$ in demonstration and local check, respectively. Further, decreased cost of Rs. 6750 per ha in higher profitability and economic viability of the technology demonstrated.
\end{abstract}


cultivation cost, scarcity of labour and energy, poor management of crop residues coupled with climate change induced weather risks are major factor for non-sustainability of intensive cereal system. Conservation agriculture based management practices and resource use efficient diversified cropping systems are developed and promoted as solutions to these challenges. It is arguably the most sustainable method of production of field crops that we have available. Moreover, to meet the targeted demand of 135-145 MT of rice by 2020 to feed the traditional 350 million people, planning and strategies are required to improve present milled rice productivity from 1.5 to $2.5 \mathrm{t} / \mathrm{ha}$ in irrigated ecosystem and from 1.5 to $2.5 \mathrm{t} / \mathrm{ha}$ in rainfed system (Balasubramanian, 1998). Mechanization appears to be an important strategy to maintain productivity of rice-wheat cropping system, besides reducing the chances of human drudgeries and cost of cultivation. It not only saves time, but also helps in improving the use efficiency of other agroinputs. In order fulfil the requirements for agriculture, domestic and industrial purpose, the dependency on groundwater in Eastern Haryana is rapidly increasing. Over the years there has been used overexploitation of ground water, which has been used to meet the increasing demand for water. In large part, this is attributable to the increased popularity of rice cultivation. Rice consumes more than 50 percent of water used for irrigation. Because of increasing water scarcity, there is need to develop alternative systems of rice cultivation that require less water. Direct seed rice (D.S.R.) is an innovation to save water, reduces cost, save time and sustains production in which the rice is grown in nonpuddled and non-saturated soil without ponded water. Therefore, more attention should be paid to direct-seeded rice to improve productivity and profitability of farmers of these areas (Singh and Singh, 2002).

\section{Materials and Methods}

Farmers' participatory front line demonstrations on method of sowing paddy (Variety, PUSA-1121) with D.S.R. machine and traditional method of sowing i.e. transplanting nursery under puddled condition as local check were conducted at ten locations covering an area of 0.4 hectare at each location under demonstration and same area was also devoted under local check during kharif (2014 and 2015) under CCS, HAU, Krishi Vigyan Kendra, Fatehabad, Haryana. The soil of the experimental locations were sandy loam in texture, low in available $\mathrm{N}$, medium in $\mathrm{P}$ and $\mathrm{K}$ with slightly alkaline in reaction ( $\mathrm{pH}-8.0$ to 8.2 ). Recommended agronomic practices were followed and data on yield and other observations were recorded from time to time at farmers' field as well as feedback was taken from the farmers and economics and benefit cost $(\mathrm{B}: \mathrm{C})$ ratio was worked out by simple tabular analysis.

\section{Results and Discussion}

The success of direct-seeded rice depends on the optimum plant population, and yields are generally affected due to less number of panicle bearing tillers per unit area. Sowing of seeds in line under direct-seeded dry conditions helps in mechanical weeding and soil and water conservation besides placement of seed in moist soil zone. In wet seeded rice, sowing of sprouted seeds by drum seeder produced yield comparable to manual transplanting. The perusal of pooled data (2014 and 2015) in Table 1 reveals that on an average $52.07 \mathrm{q} / \mathrm{ha}$ yield of paddy was recorded in demonstration plot as compared to $51.64 \mathrm{q} / \mathrm{ha}$ in local check which was 0.9 per cent higher over that of the local check. The data on economic parameters reveals that a net return of Rs.55033 per ha was in demonstration compare to Rs.47123 per ha in local check. 
Table.1 Effect of different treatment on yield and economics of paddy (Pooled data of 2014 and 2015)

\begin{tabular}{|l|l|c|c|c|c|c|}
\hline \multicolumn{1}{|c|}{ Variables } & \multicolumn{1}{|c|}{ Treatment } & $\begin{array}{c}\text { Yield } \\
\text { (q/ha) }\end{array}$ & $\begin{array}{c}\text { Gross cost } \\
\text { (Rs./ha) }\end{array}$ & $\begin{array}{c}\text { Gross return } \\
\text { (Rs./ha) }\end{array}$ & $\begin{array}{c}\text { Net return } \\
\text { (Rs./ha) }\end{array}$ & $\begin{array}{c}\text { B:C } \\
\text { ratio }\end{array}$ \\
\hline Local check & Conventional method of sowing & 51.64 & 87367 & 134490 & 47123 & $1: 1.51$ \\
\hline Demonstration & Sowing with D.S.R. machine & 52.07 & 80617 & 135650 & 55033 & $1: 1.68$ \\
\hline $\begin{array}{l}\text { Additional in } \\
\text { demonstration }\end{array}$ & -- & +0.43 & -6750 & -- & 7910 & -- \\
\hline
\end{tabular}

The benefit cost $(\mathrm{B}: \mathrm{C})$ ratio was $1: 1.68$ and $1: 1.53$ in demonstration and local check, respectively. Further, decreased cost of Rs. 6750 per ha in D.S.R. technology has increased additional net returns Rs. 7910 per ha which is 16.8 per cent higher over local check, suggesting its higher profitability and economic viability of the technology demonstrated. These results are in accordance with the findings of Yadav et al., (2011). In farmers feed back, it was observed that there is 25-30 per cent saving of water as well as less incidence of insect-pest and diseases in D.S.R. sowing.

In conclusion, however, the adoption level of D.S.R. technology is very low but the results of trials conducted on farmer's field have been very promising and the farmers have sown good enthusiasm to adopt the technology. There is a need for analysis of factors affecting adoption and acceptance of D.S.R. technology among the farmers. A lack of information on the effects and interactions on integrated weed, nutrient and pest management, which are key components of this technology. Farmers' involvement in participatory research and demonstration trials can accelerate adoption of conservation agriculture-based technologies, especially in areas where conservation agriculture is a new technology.

\section{References}

Balasubramanian, V. 1998. An introduction to direct-seeded rice system. CREMENT Workshop-cum-Group Meeting 7-9 January, DRR, Hydrabad, India.

FAO. 2016. What is Conservation Agriculture? http://www.fao.org/ag/ca/1a.html. Consulted October, 12, 2016.

Hobbs, P.R. 2007. Conservation agriculture: What is it and why is it important for future sustainable food production. The Journal of Agricultural Science 145 (02): 127-137.

Sharma, A. R., Singh, P. K. and Mishra, J. S. 2016. In Proceedings: $4^{\text {th }}$ International Agronomy Congress, Nov. 22-26, 2016, New Delhi India. Vol. 4, pp. 151-57.

Singh, R. P. and Singh, R. K. 2002. Scope of Direct-Seeded Rice in Eastern India. In Proceedings: "International workshop on herbicide resistance management and zero tillage in rice-wheat cropping system" held on 4-6 March, 2002 at CCS Haryana Agricultural University, Hisar. Pp: 196-197.

Yadav, S., Gill, G., Humphreys, E., Kukal, S. S. and Walia, U.S. 2011. Effect of water management on dry seeded and puddle transplanted rice, Part 1. Crop performance. Field Crop Research. 120: 112-22.

\section{How to cite this article:}

Satyajeet, S.P. Yadav and Dhanda, S.K. 2018. Effect of Conservation Agriculture-based Technology on Yield and Economics of Paddy. Int.J.Curr.Microbiol.App.Sci. 7(07): 67-69. doi: https://doi.org/10.20546/ijcmas.2018.707.008 